\title{
Pengaruh Otonomi Kerja terhadap Turnover Intention melalui Mediator Pemberdayaan Psikologis pada Karyawan Pertelevisian
}

\author{
Iqbal Bahtiyar Akbar ${ }^{1}$, Nida Hasanati ${ }^{2}$, Mohammad Shohib ${ }^{3}$ \\ Fakultas Psikologi, Universitas Muhammadiyah Malang \\ e-mail: ${ }^{1}$ iqbal.bahtiyar89@gmail.com, ${ }^{2}$ nida3105@gmail.com, \\ ${ }^{3}$ m.shohib.umm@gmail.com
}

\begin{abstract}
Turnover Intention is an important phenomenon that affects the development of the company. One of the factors that influence turnover intention is work autonomy. High work autonomy will increase psychological empowerment, ultimately affecting turnover intention. The purpose of this study is to determine the effect of work autonomy on turnover intention through mediators of psychological empowerment. This research approach uses a quantitative approach. The method of data collection uses the scale of The Work Design Questionnaire, the Multidimentional questionnaire of Psychological Empowerment and Mobley's Measurement Model. Determination of the sample using purposive sampling technique, the total subject is 72 people from four local television companies in Malang, Data analysis using Bootstrapping analysis. The results obtained are (1) There is no effect of work autonomy on turnover intention, the value of $F$ $=2.748$ ( $p=0.102)$; (2) There is an influence of work autonomy on psychological empowerment with a value of $F=47.07 \quad(p=0,0001)$; (3) There is no effect of psychological empowerment on turnover intention, F value $=0.654(p=0.421)$; (4) There is no mediating effect of psychological empowerment on work autonomy with turnover intention.
\end{abstract}

KEYWORDS Turnover intention, work autonomy, psychology empowerment

CITATION Akbar, I. B., Hasanati, N., \& Shohib, M. (2019). Pengaruh otonomi kerja terhadap turnover intention melalui mediator pemberdayaan psikologi pada karyawan pertelevisian. Cognicia, 7, (2), 160-174.

Sebagai penyedia kebutuhan informasi dan hiburan bagi masyarakat Indonesia, Industri pertelevisian mengalami perkembangan yang sangat pesat. Meningkatnya perkembangan industri pertelevisian di Indonesia dapat dilihat dari banyaknya televisi ditingkat nasional dan lokal yang bermunculan saat ini, tentu saja membuat persaingan antara perusahaan pertelevisian semakin sengit. Dilansir dari kominfo.go.id, berdasarkan data Ditjen PPI (2012) Indonesia terus mengalami peningkatan di industri pertelevisian, di tahun 2008, Indonesia memiliki \pm 6 stasiun televisi tingkat nasional dan tahun 2012 memiliki 62 stasiun televisi nasional. Perkembangan di industri pertelevisian tersebut tentunya akan semakin meningkat diikuti dengan perkembangan zaman sampai dengan saat ini.

Di tengah persaingan tersebut, perusahaan pertelevisian berupaya untuk memenuhi target perusahaan agar menjadi perusahaan pertelevisian nomor satu di Indonesia. Untuk memenuhi target tersebut, perusahaan pertelevisian berfokus pada 
perencanaan sumber daya manusia yang berkualitas dan berkompeten. Hal ini memicu terjadinya peningkatan kebutuhan tenaga kerja di industri pertelevisian Indonesia yang diperkirakan meningkat sebesar 1,08\% tiap tahunnya menurut perhitungan Badan Pusat Statistik (BPS) berdasarkan data Klasifikasi Baku Lapangan Usaha Indonesia (Tribowo E \& Dhewanto W, 2015). Peningkatan kebutuhan tenaga kerja tersebut dibarengi juga dengan peningkatan keluarnya pekerja di industri pertelevisian. Berdasarkan penelitian yang dilakukan oleh Mda, Mavuso, Adele (2010) tentang employee turnover, karyawan di 38 perusahaan informasi dan telekomunikasi termasuk media penyiaran yaitu industri pertelevisian di Afrika menunjukkan peningkatan angka turnover yang signifikan. Selain itu berdasarkan data yang diperoleh dari Human Resources Development tahun 2013 di salah satu perusahaan televisi nasional (Priyanka L, 2017), jumlah karyawan pada periode September 2012 Desember 2012 yang keluar sebanyak 32 orang atau 4\% dari total karyawan dan yang masuk sebanyak 21 orang atau 2\%. Sedangkan pada periode Januari 2013 - Juli 2013, karyawan yang keluar sebanyak 59 orang atau $7 \%$ dari total karyawan, dan yang masuk sebanyak 57 orang atau sebesar $6 \%$. Pada kedua periode ini, karyawan yang keluar lebih besar daripada karyawan yang masuk sehingga menimbulkan kekosongan tenaga kerja.

Employee turnover merupakan salah satu fenomena yang menjadi perhatian khusus di industri pertelevisian. Kehilangan karyawan berkualitas, kreatif serta berkompeten akan menimbulkan efek secara langsung maupun tidak langsung bagi perusahaan. Perusahaan akan memunculkan biaya untuk melakukan perekrutan, pemilihan, penerimaan, dan pelatihan pegawai baru (Abbasi S.M, Hollman K.W \& Hayes R.D, 2008). Kemungkinan bahwa seorang karyawan akan pergi atau meninggalkan pekerjaannya di dalam periode waktu tertentu disebut dengan turnover intention (Ming-Che .C, Rong-Chang .J, dkk, 2013). Menurut Toly (2001), turnover intention merupakan fenomena dan perilaku manusia yang penting dalam kehidupan perusahaan dari sudut pandang individu maupun sosial, mengingat bahwa turnover intention karyawan akan memiliki dampak yang signifikan terhadap perusahaan maupun karyawan tersebut, bahkan beberapa perusahaan merasa dirugikan ketika mengetahui proses rekrutmen yang berhasil menarik karyawan yang berkualitas pada akhirnya menjadi tidak berguna karena karyawan yang direkrut telah memilih pekerjaan di perusahaan lain. Turnover intention menjadi salah satu konstruk pendahulu turnover yang paling kuat secara kognitif (Lee, 2000). Adapun faktor-faktor yang mempengaruhi turnover intention adalah interistic motivation, job autonomy, affective commitment (Indriani Y. A, 2016), autonomy support, pemberdayaan psikologis (Liu .D, Wang .L, Zhang .S \& Lee W.T, 2011), Workplace Stress, Job Satisfication, dan Job Performance (Ming-Che C, Rong-Chang J, dkk, 2013).

Industri pertelevisian merupakan industri yang bergerak di bidang teknologi informasi dan komunikasi. Teknologi Informasi dan Komunikasi (TIK) melibatkan penyediaan layanan Internet, peralatan telekomunikasi dan layanan teknologi informasi. Selain itu, TIK juga termasuk media dan penyiaran, perpustakaan dan pusat dokumentasi, penyedia informasi komersial, layanan informasi berbasis jaringan, serta kegiatan komunikasi dan informasi terkait lainnya (She C. K, Thoong S. L, dkk, 2013). Menurut Brown (2002), karakteristik pekerjaan di industri teknologi informasi dan 
komunikasi (TIK) memberikan otonomi, tantangan, umpan balik serta kemampuan unik untuk menggunakan keterampilannya, sangatlah penting dalam meningkatkan kepuasan serta motivasi kerja. Adanya otonomi kerja sebagai salah satu karakteristik pekerjaan di industri TIK memungkinkan karyawan agar menghindari pengaruh turnover intention sehingga tetap berkomitmen terhadap organisasi, peningkatan kinerja, motivasi dan kepuasan dalam bekerja. Menurut Spector (1995), Otonomi kerja berhubungan dengan peningkatan komitmen organisasi, kinerja, keterlibatan kerja, motivasi dan kepuasan kerja serta penurunan tekanan emosional, konflik peran, absensi, dan turnover intention. Menurut Wang dan Cheng (2010), menyatakan bahwa otonomi kerja mengacu pada pemberian kesempatan bagi karyawan untuk mencoba hal baru dan kombinasi prosedur kerja yang bermanfaat.

Beberapa penelitian sebelumnya menunjukkan bahwa otonomi kerja memiliki pengaruh secara langsung terhadap turnover intention. Penelitian yang dilakukan oleh Liu D, Wang L, Zhang S \& Lee W. T. (2011), menunjukkan bahwa otonomi kerja berpengaruh terhadap turnover intention pada karyawan TI. Selain itu menurut Thompson dan Prottas (2006) menemukan bahwa otonomi kerja secara signifikan berpengaruh terhadap stres kerja, turnover intention serta konflik keluarga. Akan tetapi beberapa penelitian juga menunjukkan bahwa otonomi pada pekerjaan tidak menunjukkan pengaruh terhadap turnover intention, penelitian yang dilakukan oleh Robert C \& Satrya A (2013) menemukan bahwa otonomi kerja tidak menunjukkan pengaruh terhadap turnover intention, ada faktor-faktor lain yang mempengaruhi turnover intention karyawan. Adanya faktor-faktor lain selain otonomi kerja yang menyebabkan terjadinya turnover intention karyawan maka dibutuhkan faktor-faktor tertentu yang akan memperantarai antara otonomi kerja dengan turnover intention.

Otonomi kerja pada pekerjaan akan memunculkan empowerment (pemberdayaan) pada diri seorang karyawan. Pemberdayaan psikologis bagi seorang karyawan akan dibutuhkan ketika otonomi di perusahaan tersebut sudah teridentifikasi, perusahaan dengan otonomi yang baik akan meningkatkan pemberdayaan psikologis karyawan dalam bekerja. Menurut Ibrahim M, Abo El-Magh H. M, \& Sayed Y. H (2014), Perusahaan yang menerapkan otonomi, kebebasan, dan menciptakan atmosfer layanan yang dapat mengembangkan perasaan pemberdayaan psikologis antara para karyawan. Pemberdayaan psikologis dimaksudkan sebagai salah satu faktor yang menyebabkan terjadinya efek secara langsung maupun tidak langsung dari perpindahan karyawan secara sukarela (turnover intention). Menurut Spreitzer (1995), seseorang akan merasakan pemberdayaan terhadap dirinya maka akan mengapresiasi makna intrinsik, pilihan pribadi dan dampaknya pada pekerjaan yang mereka lakukan, pada akhirnya akan membuat dirinya tanpa ragu untuk bertahan pada pekerjaannya tersebut.

Dalam penelitian yang dilakukan sebelumnya oleh Liu .D, Wang .L, Zhang .S \& Lee W. T (2011), menemukan bahwa pemberdayaan psikologis menjadi mediator dalam hubungan otonomi kerja dan autonomy support oleh atasan terhadap turnover intention karyawan. Selain itu, penelitian sebelumnya yang dilakukan oleh Robert C \& Satrya A (2013), yang meneliti pengaruh mediator pemberdayaan psikologis antara otonomi kerja dengan turnover intention pada karyawan TI di Indonesia, menunjukkan bahwa pemberdayaan psikologis memediatori otonomi kerja dengan turnover intention 
pada karyawan TI. Pemberdayaan psikologis akan memediasi pengaruh antara otonomi kerja dengan turnover intention.

Berdasarkan penjelasan di atas dan penelitian yang telah dilakukan sebelumnya, maka sangat penting dilakukannya penelitian tentang pengaruh otonomi kerja terhadap turnover intention melalui mediator pemberdayaan psikologis pada karyawan pertelevisian. Pentingnya penelitian ini dilakukan karena jarang sekali ditemukannya penelitian tentang pengaruh otonomi kerja terhadap turnover intention melalui mediator pemberdayaan psikologis di industri pertelevisian. Terlebih pada lima tahun terakhir di Indonesia, kebanyakan penelitian tentang otonomi kerja dan turnover intention hanya berfokus di lingkungan kesehatan dan karyawan TI. Tujuan dari penelitian ini adalah untuk meneliti otonomi kerja, apakah memiliki pengaruh terhadap turnover intention melalui mediator pemberdayaan psikologis di industri pertelevisian.

Manfaat praktis dari penelitian ini adalah sebagai bahan masukan bagi organisasi agar dapat meningkatkan kualitas dari organisasi. Manfaat praktis bagi peneliti adalah sebagai penerapan ilmu-ilmu psikologi di bidang psikologi industri organisasi dan perusahaan, serta sebagai masukan bagi organisasi maupun perusahaan untuk menjadi lebih baik dari sebelumnya. Manfaat teoritis yaitu untuk pengaplikasian ilmu psikologi di bidang psikologi industri organisasi serta menambah kajian teori di bidang psikologi industri organisasi.

\section{METODE}

Dalam penelitian ini, metode yang digunakan yaitu melalui pendekatan kuantitatif. Menurut Sugiyono (2003), metode kuantitatif merupakan penelitian dengan memperoleh data yang dihasilkan berbentuk angka. Peneliti akan mengembangkannya sesuai dengan tujuan penelitian. Berdasarkan teori tersebut, penelitian kuantitatif merupakan data yang diperoleh dari sampel dan populasi penelitian dianalisis sesuai dengan metode statistik yang digunakan. Dalam penelitian ini dimaksudkan untuk mengetahui seberapa besar pengaruh otonomi kerja terhadap turnover intention melalui mediator pemberdayaan psikologis yang dilengkapi analisis data sehingga dapat dipahami dan mendapatkan kesimpulan. Penelitian ini dilakukan dengan menggunakan skala sebagai bahan pengumpulan data.

Pada penelitian ini, populasi yang diteliti yaitu karyawan pertelevisian. Berdasarkan populasi tersebut, pengambilan sampel dalam penelitian ini yaitu menggunakan metode purposive sampling. Menurut Sugiyono (2013) purposive sampling adalah teknik pengambilan sampel sumber data dengan pertimbangan tertentu. Pertimbangan tersebut berdasarkan kriteria yang telah ditentukan. Sampel yang digunakan pada penelitian ini yaitu karyawan perusahaan pertelevisian lokal dengan jumlah 72 orang. Penelitian ini dilakukan pada karyawan pertelevisian lokal yang bekerja sebagai karyawan tetap di Malang atau karyawan pertelevisian yang telah bekerja $\pm 3-12$ bulan atau lebih, usia minamal \pm 18 tahun dan maksimal tidak ditentukan. Kriteria pendidikan mencakup SMA, Diploma dan Sarjana, selain itu status pernikahan juga masuk kedalam salah satu kriteria pada penelitian ini. Terdapat empat perusahaan pertelevisian yang berlokasi di Malang sebagai tempat penelitian. 
Penelitian ini terdapat variabel bebas $(X)$ dan variabel terikat $(Y)$ serta variabel mediator $(\mathrm{M})$. Variabel bebas $(\mathrm{X})$ yang digunakan yaitu otonomi kerja sedangkan variabel terikat $(\mathrm{Y})$ yang digunakan yaitu turnover intention serta variabel mediator $(\mathrm{M})$ yaitu pemberdayaan psikologis.

Otonomi kerja (X) melibatkan sejauh mana perusahaan memberikan kebijaksanaan dan kemandirian menjadwalkan pekerjaan pada karyawan, membuat keputusan, dan memilih prosedur dan metode untuk melakukan kegiatan karyawan. Otonomi kerja diukur dengan menggunakan 9 item pernyataan yang terdiri dari tiga komponen yaitu; (1) Work Scheduling Autonomy; (2) Decision-making Autonomy; dan (3) Work Methods Autonomy yang merupakan bagian dari Job Characteristic Model terdapat pada The Work Design Questionnaire yang telah dikembangkan oleh Morgeson \& Humphrey (2006). Ketiga komponen dari Otonomi kerja mencakup 3 item tiap komponennya yang memiliki nilai reliabilitas sebesar $0.85 ; 0,85$; dan 0,88.

Pemberdayaan Psikologis (M) merupakan suatu keyakinan karyawan akan tingkatan dimana mereka mempengaruhi lingkungan kerja mereka, kompetensi mereka, seberapa berartinya pekerjaan mereka dan otonomi yang mereka rasakan di dalam pekerjaan. Pemberdayaan psikologis diukur dengan menggunakan 12 item pernyataan yang dikembangkan oleh Spreizer M. G (1995) berdasarkan Multidimentional questionnaire of Psychological Empowerment, terdiri dari empat indikator yaitu meaning, competence, self-determination dan impact. Setiap indikator terdiri dari 3 item dengan nilai reliabilitas sebesar $0,78,0,84,0,83$ dan 0,90 .

Turnover intention (Y) yaitu sebagai salah satu indikator untuk kemungkinan seseorang karyawan akan meninggalkan organisasi tempat dia bekerja dalam waktu dekat. Turnover intention diukur dengan menggunakan 10 item berdasarkan 5 dimensidimensi turnover intention berdasarkan Mobley's Measurement Model menurut Hom P. W \& Griffeth R. W(1991), yaitu; (1) Individu berfikir untuk meninggalkan organisasi; (2) Individu ingin mencari pekerjaan pada organisasi atau perusahaan lain; (3) Individu ingin meninggalkan organisasi atau perusahaan; (4) Individu ingin meninggalkan organisasi dalam waktu dekat; (5) Individu ingin meninggalkan organisasi bila ada kesempatan yang lebih baik.

Teknik pengumpulan data yang digunakan dari keseluruhan instrumen yaitu dengan menggunakan jenis skala likert dengan menggunakan lima pilihan jawaban yaitu sangat setuju (SS) bernilai 5, setuju (S) bernilai 4, ragu-ragu (RR) bernilai 3, tidak setuju (TS) bernilai 2 dan sangat tidak setuju (STS) bernilai 1 .

Tabel 1. Indeks Validitas dan Reliabilitas Hasil Tryout

\begin{tabular}{lccc}
\hline \multicolumn{1}{c}{ Alat Ukur } & $\begin{array}{c}\text { Jumlah Item } \\
\text { Valid }\end{array}$ & Indeks Validitas & $\begin{array}{c}\text { Indeks } \\
\text { Reliabilitas }\end{array}$ \\
\hline Otonomi Kerja & 8 & $0,279-0,569$ & 0,731 \\
Pemberdayaan & 10 & $0,273-0,565$ & 0,713 \\
Psikologis & & & \\
Turnover Intention & 9 & $0,298-0,619$ & 0,781 \\
\hline
\end{tabular}

Item dikatakan valid apabila nilai Rhitung > Rtabel. Nilai Rtabel yaitu 0,257. Setalah dilakukan tryout masing-masing variabel terdiri dari delapan item otonomi 
kerja dengan nilai reliabilitas sebesar 0,731. 10 item pemberdayaan psikologis dengan nilai reliabilitas sebesar 0,713 . Sembilan item turnover intention dengan nilai reliabilitas sebesar 0,781 .

Penelitian ini menggunakan pendekatan metode analisis mediator yang dikembangkan oleh Hayes (2013) dengan metode bootstrapping, metode ini merupakan pengembangan dari cara analisis regresi dengan variabel mediator dengan model efek kausal berdasarkan panduan dari Baron dan Kenny (1986) dan dengan Sobel Test. Cara analisis regresi dengan variabel mediator dengan metode bootstrapping bertujuan untuk mengetahui makna dan implikasi sebab akibat dari model mediasi disajikan diikuti dengan penjelasan tentang efek langsung, tidak langsung, dan total. Pengolahan data dalam penelitian ini menggunakan SPSS for windows versi 22 dengan tambahan add-ons yaitu PROCESS v3.0 for SPSS. Sebelum dilakukan analisis, terlebih dahulu dilakukan beberapa prosedur-prosedur penelitian.

Prosedur dalam penelitian ini memiliki beberapa tahapan pelaksanaan, tahap pertama pada penelitian ini yaitu persiapan awal dengan berdiskusi permasalahan kepada kedua dosen pembimbing. Kemudian peneliti melakukan studi pendahuluan, perumusan masalah, penentuan kajian teori dan hipotesis, menentukan variabel beserta metode pengumpulan data, serta menentukan instrumen penelitian dan analisis data yang digunakan. Setelah tahap tersebut, peneliti melakukan seminar proposal yang sebelumnya telah disetujui oleh dosen pembimbing satu dan dua sebagai standar perizinan untuk melakukan penelitian. Tahap kedua, peneliti melakukan penyebaran skala untuk menentukan uji validitas dan reliabilitas instrumen penelitian. Setelah memperoleh hasil dari validitas dan reliabilitas setiap item pada masing-masing variabel, tahapan ketiga yaitu melakukan uji hipotesis dan analisis regresi menggunakan metode bootstrapping (Hayes, 2013).

\section{HASIL}

Setelah dilakukannya penelitian, hasil yang didapatkan berdasarkan deskripsi subjek meliputi jenis kelamin, usia, pendidikan terakhir, dan masa kerja yaitu sebagai berikut :

Tabel 2. Deskripsi Hasil Subjek Penelitian

\begin{tabular}{lcc}
\hline Kategori & Jumlah & Persentase \\
\hline Jenis Kelamin & & \\
$\quad$ Laki-Laki & 56 & $78 \%$ \\
$\quad$ Perempuan & 16 & $22 \%$ \\
Usia & & \\
$\quad$ 18-25 Tahun & 28 & $39 \%$ \\
26-34 Tahun & 37 & $51 \%$ \\
35-48 Tahun & 7 & $10 \%$ \\
Pendidikan Terakhir & & \\
$\quad$ SMA & 17 & $24 \%$ \\
$\quad$ Diploma & 28 & $39 \%$ \\
Sarjana & 27 & $37 \%$
\end{tabular}




\begin{tabular}{lll} 
Status & & \\
$\quad$ Menikah & 23 & $32 \%$ \\
$\quad$ Belum Menikah & 49 & $68 \%$ \\
Masa Kerja & & \\
0,25-1 Tahun & 19 & $26,4 \%$ \\
1,1-5,3 Tahun & 34 & $47,2 \%$ \\
6-16 Tahun & 19 & $26,4 \%$ \\
\hline Total & 72 & $100 \%$ \\
\hline
\end{tabular}

Berdasarkan tabel di atas, hasil yang didapatkan yaitu subjek penelitian berjumlah 72 karyawan dengan jumlah laki-laki lebih banyak dibandingkan perempuan yaitu laki-laki 56 orang atau 78\% dan rentang usia 26-34 tahun mendominasi terbanyak dari 72 karyawan yaitu sebesar $51 \%$ atau 37 orang karyawan. Status menikah yang terbanyak yaitu status belum menikah yaitu sebesar $68 \%$ atau 49 orang, serta kriteria masa kerja terbanyak pada rentang 1,1-5,3 tahun sebesar 34 orang atau $47,2 \%$.

Tabel 3. Deskripsi Variabel (T-Score)

\begin{tabular}{lcccc}
\hline Variabel & \multicolumn{2}{c}{ Tinggi } & \multicolumn{3}{c}{ Rendah } \\
\hline & Jumlah & Frekuensi & Jumlah & Frekuensi \\
\hline Otonomi Kerja & 26 & $36 \%$ & 46 & $64 \%$ \\
$\begin{array}{l}\text { Pemberdayaan } \\
\text { Psikologis }\end{array}$ & 35 & $49 \%$ & 37 & $51 \%$ \\
$\begin{array}{l}\text { Turnover } \\
\text { Intention }\end{array}$ & 28 & $39 \%$ & 44 & $61 \%$ \\
\hline
\end{tabular}

Berdasarkan hasil uji T-score di atas menunjukkan bahwa dari 72 orang karyawan berasal dari empat pertelevisian di Malang, 26 (36\%) karyawan memiliki tingkat otonomi tinggi, sedangkan $46(64 \%)$ orang lainnya memiliki tingkat otonomi yang rendah. Pemberdayaan psikologis karyawan dengan jumlah 35 (49\%) orang memiliki tingkat pemberdayaan psikologis yang tinggi, sedangkan 37 (51\%) orang memiliki tingkat pemberdayaan psikologis yang rendah. Tingkat turnover intention dari jumlah 72 karyawan, 28 (39\%) orang memiliki tingkat turnover intention yang tinggi dan 44 (61\%) sisanya, memiliki tingkat turnover intention yang rendah.

Setelah dilakukan uji asumsi normalitas menggunakan uji skewness dan kurtosis menggunakan SPSS V.22, hasil yang diperoleh yaitu ketiga variabel penelitian memilki distribusi data normal. Distribusi data tersebut dilihat berdasarkan nilai Zskewness dan Zkurtosis pada masing-masing variabel penelitian, nilai tersebut harus berada diantara taraf signifikansi $5 \%$ yaitu $\pm 1,96$. Penentuan nilai Zskewness dan Zkurtosis dihitung dengan membagi nilai skewness dan std. error skewness serta nilai kurtosis dan std. error kurtosis. Nilai Zskewness dari otonomi kerja yaitu -0,722, pemberdayaan psikologis sebesar -0,601, dan turnover intention sebesar -0,721. Nilai Zkurtosis dari otonomi kerja 
yaitu -0,166, pemberdayaan psikologis sebesar -0,172 dan turnover intention sebesar 1,552. Berdasarkan hasil Zskewness dan Zkurtosis pada masing-masing variabel penelitian tersebut, secara keseluruhan nilai Zskewness dan Zkurtosis berada diantara $\pm 1,96$, maka seluruh variabel penelitian berdistribusi normal. Selain itu, berdasarkan analisis uji linearitas diperoleh hasil bahwa keseluruhan hubungan antara variabel $X$ dan $Y, X$ dan $M$ serta M dan Y memiliki hubungan linear, dibuktikan dengan nilai sig. $>0,05$.

Tabel 4. Uji Hipotesis Penelitian

\begin{tabular}{cccccc}
\hline Variabel & $\mathbf{F}$ & $\mathbf{r}$ & $\mathbf{r}^{2}$ & $\mathbf{B}$ & $\mathbf{P}$ \\
\hline $\mathrm{X}-\mathrm{Y}^{(\mathrm{a})}$ & 2,748 & 0,194 & 0,038 & -0.343 & 0,102 \\
$\mathrm{X}-\mathrm{M}^{(\mathrm{b})}$ & 47,07 & 0,634 & 0,402 & 0.762 & 0,000 \\
$\mathrm{M}-\mathrm{Y}^{(\mathrm{c})}$ & 0,654 & 0,096 & 0,009 & -0.141 & 0,421 \\
\hline
\end{tabular}

Keterangan :

$\mathrm{a}=$ Otonomi Kerja - Turnover Intention

$\mathrm{b}=$ Otonomi Kerja - Pemberdayaan Psikologis

$\mathrm{c}=$ Pemberdayaan Psikologis - Turnover Intention

Uji hipotesis pertama yaitu pengaruh variabel otonomi kerja $(X)$ terhadap turnover intention $(\mathrm{Y})$, hasil yang diperoleh dengan nilai $\mathrm{F}=2,748(\mathrm{p}<0,05)$, dengan nilai p sebesar 0,102. Hasil tersebut menunjukkan bahwa otonomi kerja $(X)$ tidak memiliki pengaruh yang signifikan terhadap turnover intention (Y). Nilai $\mathrm{r}^{2}$ menunjukkan bahwa otonomi kerja (X) memberikan pengaruh sebesar 3,8\% sisanya sebesar 96,2\% dipengaruhi oleh faktor-faktor lain.

Uji hipotesis kedua yaitu pengaruh variabel otonomi kerja $(X)$ terhadap pemberdayaan psikologis $(M)$, hasil yang diperoleh dengan nilai $F=47,07(p<0,05)$, nilai $\mathrm{p}$ sebesar 0,0001 . Hasil tersebut menunjukkan bahwa otonomi kerja $(X)$ memiliki pengaruh signifikan terhadap pemberdayaan psikologis (M). Nilai $\mathrm{r}^{2}$ menunjukkan bahwa otonomi kerja (X) memberikan pengaruh sebesar $40,2 \%$ sisanya sebesar $59,8 \%$ dipengaruhi oleh faktor-faktor lain. Nilai B menunjukan besaran koefisien otonomi kerja $(X)$ terhadap pemberdayaan psikologis $(\mathrm{M})$ sebesar 0,762 artinya setiap penambahan $1 \%$ tingkat otonomi kerja, maka pemberdayaan psikologis meningkat sebesar 0,762. Karena nilai koefisien regresi bernilai plus (+) maka dapat dikatakan bahwa otonomi kerja bengaruh positif terhadap pemberdayaan psikologis.

Uji hipotesis ketiga yaitu pengaruh variabel pemberdayaan psikologis (M) terhadap turnover intention ( $Y)$, hasil yang diperoleh dengan nilai $F=0,654(p<0,05)$, nilai p sebesar 0,421 . Hasil tersebut menunjukkan bahwa pemberdayaan psikologis (M) tidak memiliki pengaruh signifikan terhadap turnover intention (Y). Nilai $\mathrm{r}^{2}$ menunjukkan bahwa pemberdayaan psikologis (M) memberikan pengaruh sebesar $0,9 \%$ sisanya sebesar $99,1 \%$ dipengaruhi oleh faktor-faktor lain. 
Tabel 5. Pengaruh Otonomi Kerja terhadap Turnover Intention melalui Pemberdayaan Psikologis

\begin{tabular}{cccc}
\hline Total effect X on Y & $\begin{array}{c}\text { Indirect effect X } \\
\text { on } Y\end{array}$ & BootLLCI & BootULCI \\
\hline$-0,3431$ & 0,0506 & $-0,371$ & 0,454 \\
\hline
\end{tabular}

Hasil pada tabel di atas adalah hasil bootstrapping, hasil tersebut menunjukkan pengaruh tidak langsung otonomi kerja terhadap turnover intention, batasan CI (taraf kepercayaan) berkisar antara -0,371 - 0,454. Diantara batasan CI tersebut mencakup nilai 0 di dalamnya, maka pengaruh tidak langsung yang dihasilkan bersifat tidak signifikan dan tidak terjadi efek mediasi. Berdasarkan data tersebut, maka hasil hipotesis keempat pengaruh otonomi kerja terhadap turnover intention tidak diperantarai oleh pemberdayaan psikologis. Tabel total effect menunjukkan pengaruh total variabel $X$ terhadap $Y$ sebesar $-0,3431$. Efek tidak langsung atau indirect effect antara variabel $X$ dan $Y$ yaitu 0,0506. Dapat disimpulkan bahwa tidak terjadi pengaruh signifikan antara variabel $\mathrm{X}$ terhadap $\mathrm{Y}$ dan tidak terjadi efek mediasi variabel $\mathrm{M}$.

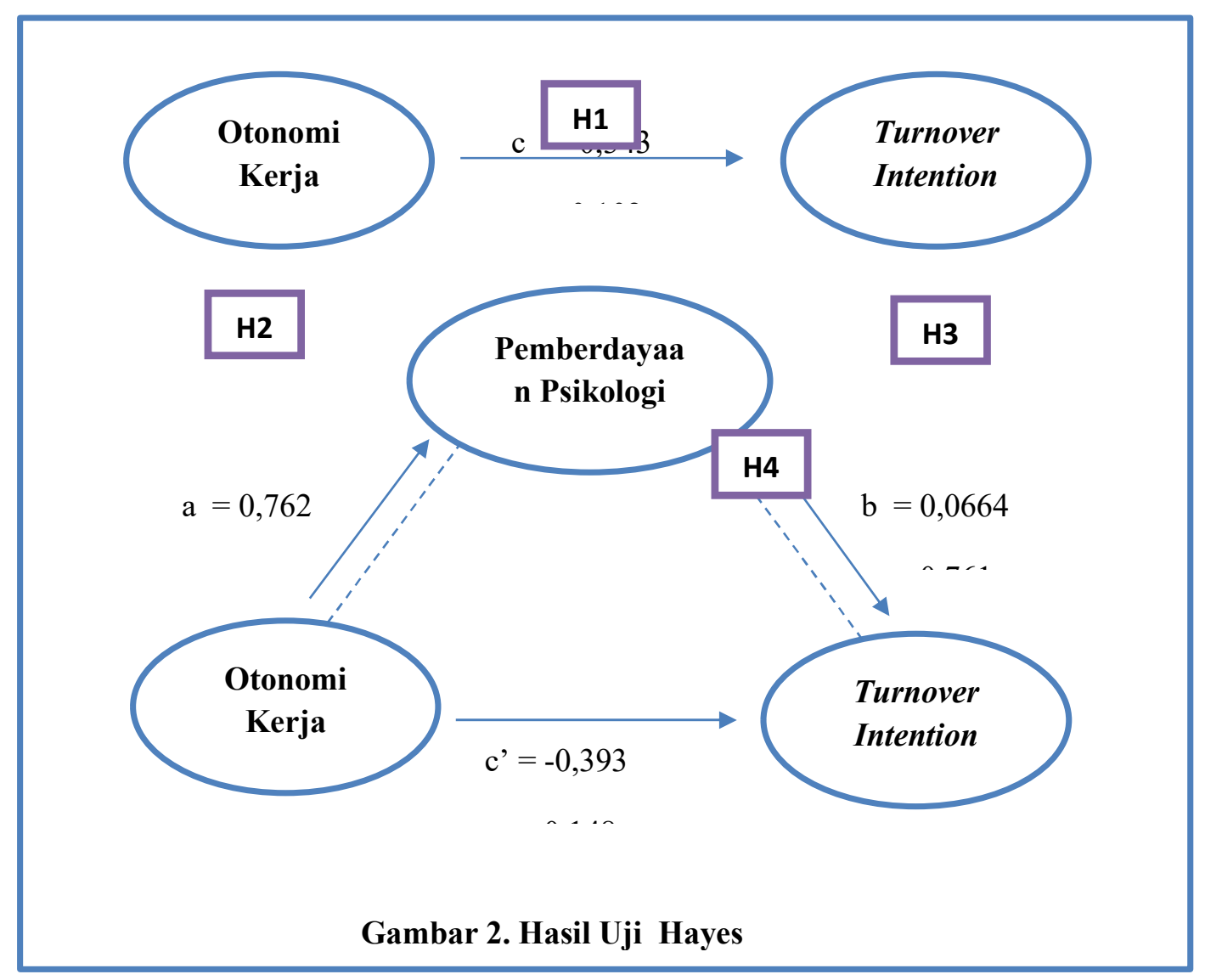

Dalam penelitian ini, ada empat hipotesis yang diujikan yaitu hipotesis pertama yaitu Adanya pengaruh negatif otonomi kerja $(\mathrm{X})$ terhadap turnover intention $(\mathrm{Y})$; (2) Adanya pengaruh positif otonomi kerja $(\mathrm{X})$ terhadap pemberdayaan psikologis $(\mathrm{M})$; (3) Adanya pengaruh negatif pemberdayaan psikologis $(\mathrm{M})$ terhadap turnover intention $(\mathrm{Y})$; 
(4) Otonomi kerja $(X)$ secara tidak langsung berpengaruh terhadap (Y) turnover intention melalui Pemberdayaan Psikologis.

Sesuai dengan hipotesis penelitian, hasil pada hipotesis pertama yakni ditolak, hasil tersebut menyatakan bahwa tingkat otonomi kerja yang tinggi maupun rendah tidak memberikan pengaruh terhadap turnover intention atau intensitas keluar masuknya karyawan, di perusahaan pertelevisian lokal di Malang. Perolehan hasil tersebut dilatar belakangi karena berbagai faktor.

Pada kenyataannya faktor yang melatar belakangi yaitu karena tingkat otonomi kerja pada pertelevisian lokal di Malang rendah, menurut ATVLI (Asosiasi Televisi Lokal Indonesia) tahun 2018, perusahaan pertelevisian khususnya pertelevisian lokal pada kenyataannya memang menerapkan kebebasan bekerja karyawan, seperti penerapan sistem teknologi penyiaran dengan teknologi digital khususnya pada sistem perangkat studio untuk memproduksi program, melakukan penyuntingan, perekaman dan penyimpanan data, aktifitas-aktifitas tersebut dilakukan dengan menerapkan kebebasan berkreasi dan menyalurkan ide-ide dari karyawan, akan tetapi ada salah satu permasalahan yang dihadapi perusahaan pertelevisian lokal sehingga membatasi otonomi kerja seorang karyawan dalam bekerja di perusahaan pertelevisian lokal yaitu adanya persoalan Rancangan Peraturan Pemerintah tentang penyiaran lokal dalam realitanya sangat tidak sejalan dengan UU Penyiaran, yang seharusnya di pegang oleh Komisi Penyiaran Indonesia (KPI), banyak terpangkas dengan kewenangan Pemerintah yang terlalu besar. Masuknya kewenangan-kewenangan pemerintah daerah membatasi otonomi kerja karyawan, karyawan kurang merasakan dukungan untuk menjalankan otonomi kerja yang seharusnya, karyawan merasakan pekerjaannya tidak memungkinkan kebebasan, kebijaksanaan dan kemandirian menjadwalkan pekerjaan, membuat keputusan, dan memilih prosedur dan metode untuk melakukan kegiatan. Menurut Naqvi, Isgtiaq, Kanwal, N \& Ali, M (2013), ketika karyawan diberikan dukungan untuk menjalankan otonomi, mereka akan mempertimbangkan bahwa mereka dipercaya melakukan tugasnya. Ini mengarah pada peningkatan level motivasi intrinsik dan hasilnya akan meningkatkan kepuasan dalam bekerja maupun yang terjadi sebaliknya ketika karyawan tidak diberikan dukungan yang terjadi adalah penurunan level motivasi dan kepuasan dalam bekerja.

Otonomi kerja yang tinggi akan mempengaruhi kepuasan kerja karyawan. Menurut Khatri N, Budhwar P dan Chong T. F, (2001), otonomi kerja masuk ke dalam salah satu representasi dari job satisfaction atau kepuasan kerja penelitian tersebut. Kepuasan kerja pada penelitian tersebut dilakukan dengan menggunakan tingkat upah, sifat pekerjaan dan pengawasan. Selain itu, pada penelitian tersebut membuktikan tidak adanya pengaruh antara tingkat otonomi kerja dengan tingkat turnover intention karyawan, otonomi kerja masuk ke dalam kategori sifat pekerjaan dan sifat pekerjaan tidak membuktikan adanya pengaruh terhadap turnover intention karyawan.

Pada penelitian ini, tingkat turnover intention karyawan pertelevisian lokal di Malang tergolong rendah, sesuai dengan hasil wawancara yang didapatkan sebagian perusahaan memiliki sistem pembagian keuntungan untuk karyawan, karyawan memiliki hak untuk mendapatkan bonus sesuai dengan jumlah iklan yang masuk. Dengan banyaknya bonus yang diberikan kepada karyawan apabila ada banyak iklan yang masuk, maka sesuai dengan penelitian yang dilakukan oleh Khatri N, Budhwar P 
dan Chong T.F, (2001), yang menjelaskan bahwa upah menjadi faktor yang menyebabkan tingkat turnover intention rendah. Karyawan tidak mempedulikan faktor-faktor lain yang dapat menyebabkan munculnya keinginan untuk keluar dari pekerjaannya salah satunya yaitu faktor otonomi kerja.

Hipotesis kedua diterima, hipotesis kedua menunjukkan hasil yang berbeda, hasil yang didapatkan yaitu otonomi kerja berpengaruh secara signifikan dan berkorelasi positif terhadap pemberdayaan psikologis karyawan. Hasil tersebut menyatakan bahwa tingkat otonomi kerja yang tinggi atau rendah akan berpengaruh terhadap tingkat pemberdayaan psikologis yang tinggi atau rendah pula pada karyawan pertelevisian lokal di Malang.

Pada penelitian yang dilakukan oleh Hackman \& Oldham (1976), otonomi kerja memberikan pengaruh positif terhadap munculnya pemberdayaan psikologis karyawan. Apabila tingkat otonomi kerja tinggi maka tingkat pemberdayaan psikologis juga tinggi, sebaliknya apabila tingkat otonomi kerja rendah maka tingkat pemberdayaan psikologis juga rendah. Beberapa bukti yang ditemukan dilapangan yaitu, karakteristik pekerjaan dari ke empat perusahaan di Malang tidak memungkinkan kebebasan, kebijaksanaan dan kemandirian menjadwalkan pekerjaan, membuat keputusan, dan memilih prosedur dan metode untuk melakukan kegiatan karena adanya keterlibatan pemerintah daerah. Bukti tersebut menyebabkan tingkat otonomi kerja yang rendah yang akan mempengaruhi pemberdayaan psikologis yang rendah pula. Karyawan dengan otonomi kerja yang rendah akan merasakan dampak terhadap pemberdayaan psikologis yang rendah terhadap pekerjaan yang telah dilakukannya dan mempengaruhi kinerja perusahaan secara keseluruhan. Karyawan tidak merasakan keyakinan akan tingkatan dimana mereka mempengaruhi lingkungan kerja mereka, kompetensi mereka, seberapa berartinya pekerjaan mereka dan otonomi yang mereka rasakan di dalam pekerjaan.

Hipotesis ketiga yang menguji pengaruh antara variabel pemberdayaan psikologis terhadap turnover intention, hipotesis ketiga ditolak dan tidak terjadi pengaruh yang signifikan. Hasil tersebut menyatakan bahwa tingkat pemberdayaan psikologis yang tinggi maupun rendah tidak memberikan pengaruh terhadap turnover intention atau intensitas keluar masuknya karyawan perusahaan pertelevisian lokal di Malang.

Sejalan dengan penelitian yang dilakukan oleh Kim, Y.S \& Fernandez, S (2015), mereka menjelaskan bahwa pemberdayaan psikologis memiliki pengaruh yang kecil dan bahkan tidak memiliki pengaruh yang signifikan terhadap turnover intention. Faktor-faktor seperti kelayakan pensiun dan keuangan memiliki pengaruh yang lebih besar daripada pemberdayaan psikologis seorang karyawan. Kenyataannya, karyawan pertelevisian lokal di Malang memiliki tingkat pemberdayaan yang rendah, karyawan tidak merasakan keyakinan akan tingkatan dimana mereka mempengaruhi lingkungan kerja mereka, kompetensi mereka, seberapa berartinya pekerjaan mereka dan otonomi yang mereka rasakan di dalam pekerjaan. Upah/ bonus menjadi salah satu faktor yang menyebabkan tidak adanya pengaruh terhadap turnover intention. Karyawan pertelevisian lokal di Malang hanya bekerja sebatas kebutuhan materilitas sehingga dampak yang terjadi, karyawan kurang merasakan seberapa berartinya pekerjaan yang mereka lakukan, keyakinan akan tingkatan dimana mereka 
mempengaruhi lingkungan kerja mereka, kompetensi mereka dan otonomi yang mereka rasakan di dalam pekerjaan. Selain itu penelitian yang dilakukan oleh Meriane, Keren Fransisca (2016), bahwa pemberdayaan psikologis masih tergolong rendah bagi karyawan Divisi Sales dan Marketing PT Suburjaya Makmur Lestari dengan aspek pemberdayaan psikologis seperti "sense of meaning", "sense of competence", "sense of self determination" dan "sense of impact" yang berpengaruh terhadap turnover intention. Beberapa faktor-faktor di atas merupakan alasan tidak berpengaruhnya pemberdayaan psikologis terhadap turnover intention karyawan secara signifikan.

Hipotesis keempat ditolak dengan hasil yaitu pengaruh tidak langsung yang dihasilkan otonomi kerja bersifat tidak signifikan dan tidak terjadi efek mediasi. Dengan hal tersebut variabel pemberdayaan psikologis sebagai variabel mediator antara otonomi kerja dan turnover intention tidak memiliki pengaruh yang signifikan apabila dikontrol maupun ditiadakan.

Ada beberapa hal yang menjadi keterbatasan dalam penelitian ini yaitu; (1) penelitian ini menguji pada karakteristik pekerjaan yang general atau secara keseluruhan pada karyawan pertelevisian, pada akhirnya tidak mendapatkan hasil maksimal sesuai dengan hipotesis yang diujikan; (2) penelitian ini juga tidak memaparkan dan mengontrol faktor-faktor lain yang menjadi penyebab munculnya otonomi kerja, pemberdayaan psikologis serta turnover intention, faktor-faktor seperti tingkat keuangan, lingkungan pekerjaan (internal), interpretasi individu terkait perubahan lingkungan pekerjaan (eksternal), keterikatan kerja, kepuasan kerja maupun faktor-faktor lainnya yang dipercaya mampu mempengaruhi variabel otonomi kerja, pemberdayaan psikologis dan turnover intention.

\section{SIMPULAN DAN IMPLIKASI}

Berdasarkan hasil dari penelitian ini, kesimpulan yang didapatkan yaitu tidak ada pengaruh signifikan antara otonomi kerja dengan turnover intention melalui perantara pemberdayaan psikologis dari empat perusahaan pertelevisian lokal di Malang, pemberdayaan psikologis menjadi variabel mediasi yang tidak memiliki peran mediasi. Selain itu, hasil dari otonomi kerja terhadap turnover intention membuktikan bahwa tinggi rendahnya tingkat otonomi kerja tidak mempengaruhi tingkat turnover intention karyawan dari empat perusahaan pertelevisian lokal di Malang. Akan tetapi otonomi kerja memiliki pengaruh yang signifikan terhadap pemberdayaan psikologis, semakin tinggi atau rendahnya otonomi kerja karyawan akan mempengaruhi tinggi rendahnya pemberdayaan psikologis yang dimiliki seorang karyawan.

Implikasi yang didapatkan dari penelitian ini yaitu perusahaan diharapkan menjadi wadah maupun perantara terhadap otonomi karyawan dalam bekerja terhadap pengaruh eksternal perusahaan dengan tetap memberikan kebebasan menjadwalkan tugas, memilih prosedur serta metode dalam bekerja, selain itu dengan memberikan kesempatan untuk berdiskusi antar karyawan, sharing melalui berbagai macam pendekatan akan meningkatkan pemberdayaan yang dialami oleh karyawan sehingga karyawan akan lebih merasakan perannya dalam bekerja. Bagi penelitian selanjutnya diharapkan lebih memperhatikan karakteristik pekerjaan yang melibatkan 
otonomi kerja yang akan diangkat pada karyawan pertelevisian untuk mendapatkan hasil maksimal pada setiap variabel yang diteliti.

\section{REFERENSI}

Abbasi, S.M., Hollman, K.W., \& Hayes, R. D. (2008). Bad Bosses and How not to be One. Information Management Journal, 42, 52-56.

Agusramadani \& Amalia, L. (2018). The Influence of Job Involvement and Job Satisfaction Toward Employee Turnover Intention (Case in Indonesia Broadcasting). IOSR Journal of Business and Management 20(5) V 11-18. Esa Unggul University.

Andini, R. (2010). Analisis Pengaruh Kepuasan Gaji, Kepuasan Kerja, Komitmen Organisasional Terhadap Turnover Intention (Studi Kasus Pada Rumah Sakit Roemani Muhammadiyah Semarang). Tesis Magister Manajemen. Universitas Diponegoro.

ATVLI (Asosiasi Televisi Lokal Indonesia). (2008). Awal Perjalanan Asosiasi Televisi Lokal Indonesia. Surat Deklarasi Asosiasi Televisi Lokal Indonesia. Bali.

Brown, M, M. (2002). An exploratory study of job satisfaction and work motivation of a selected group of information technology consultants in the Delaware Valley. Doctoral Dissertation. Wilmington College: United States.

Chung, E. (2017). The Relationship between Otonomi kerja, Job Satisfaction and The Mediating Role of Job Crafting. Journal of School of Social and Behavioral Sciences 115674. University of Tilburg.

Collins, D, M. (2007). Understanding The Relationships Between Leader-Member Exchange (Lmx), Psychological Empowerment, Job Satisfaction, And Turnover Intent In A Limited-Service Restaurant Environment. Electronic Thesis or Dessertation: The Ohio State University.

Conger, J. A \& Kanungo, R. N. (1988). The empowerment process: Integrating theory and practice. Academy of Management Review; 13(3), 471 - 482.

Dess, G,G \& J,D, Shaw. (2001). Voluntary turnover, social capital, and organizational performance. Academy management review, 26: 446-456

Hackman, J, R., \& Oldham, G, R. (1976). Motivation through the design of work: test of theory. Organizational Behavior and Human Performance, 16, 250-279.

Hayes, Andrew F. (2013). Introduction to Mediation, Moderation, and Conditional Process Analysis: A Regression-Based Approach. New York, NY: The Guilford Press.

Hom, P, W \& Griffeth, R,W. (1991). Structural Equations Modeling Test of a Turnover Theory: Cross Seletional and Longitudinal Analyses. Journal of Applied Psychology, 76, 350-366.

Huysse-Gaytandjieva, A., Groot, W. \& Pavleva, M. (2013). Why do some employees fall into and fail to exit a job-lock situation?. Journal of environemntal and Public Health 839349. 1-14.

Ibrahim, M, M., Abo El-Magh, H, M., \& Sayed, Y, H. (2014). Nurse's Psychological Empowerment and Perceived Autonomy in University and Teaching Hospitals at Menofia Governorate/Egypt. Journal of Nursing Education and Practice 4(9).

Indriani, Y, A. (2016). Pengaruh Interinsic Motivation, Otonomi kerja dan Affective Commitment Terhadap Turnover Intention (Kasus Pada Rumah Sakit Kasih Ibu Surakarta). Jurnal Publikasi Ilmiah. Universitas Muhammadiyah Surakarta.

Jackofsky, F, E \& Jr, Slocum, W, J. (1987). A Causal Analysis of The Impact of Job Performance on The Voluntary Turnover Process. Journal of Occupational Behaviour, 8, 263-270. Southern Methodist University Dallas.

Jewell, L. N. \& Siegall, M. 1998. Psikologi Industri/ Organisasi Modern (Terjemahan). Arcan 158(7) JEW p: Jakarta.

Karasek, R., Brisson, C., Kawakami, N., Houtman, I., Bongers, P., \& Amick, B. (1998). The Job Content Questionnaire (JCQ): an instrument for internationally comparative assessments of psychosocial job characteristics. Journal of occupational health psychology, 3(4), 322. 
Khatri, N., Budhwar, P., \& Choung, T, F. (2001). Explaining employee turnover in an Asian context. Human Resources Management Journal, 11(1), 54-74.

Kim, Y, S., \& Fernandez, S. (2015). Employee Empowerment and Turnover Intention in the U.S Federal Bureaucrazy. American Review of Public Administration, 1-19.

Kreitner, R \& Knicki, A. (1995). Organizational Behaviour (Third Edition). Chicago xxii, 605p: United States of America.

Lee, P.C.B. (2000). Turnover of Information Technology Professionals: a contextual model. Accounting Management and Information Technologies, 10, 101-124.

Liu, D., Wang, L., Zhang, S., \& Lee, W.T. (2011). The Effects of Autonomy and Empowerment on Employee Turnover: Test of a Multilevel Model in Teams. Journal of Applied Psychology, 96(6), 1305-1316. American Psychological Assosiation.

Liu, C., Spector, P.E., \& Jex, S.M. (2005). The relation of job control with job strains: A comparison of multiple data sources. Journal of Occupational and Organizational Psychology, 78, 325-336.

Maertz, C.P., \& Griffeth, R.W. (2004). Eight motivational forces and voluntary turnover: a theoretical synthesis with implications for research. Journal of Management, 30(5), 667-683.

Mayhew, R. (2010). An Example of Job Autonomy. Retrieved from http://work.chron.com/example-job-autonomy-15680.html.

Meriane, Keren Fransisca. (2016). Pengaruh Pemberdayaan dan Kepuasan Kerja terhadap Turnover Intention Divisi Sales dan Marketing PT Suburjaya Makmur Lestari. Undergraduate Thesis. Universitas Kristen Maranatha .

Mda, Mavuso, Adele. (2010). Staff Turnover in the Information and Communication Technology (ICT) Sector in South Africa. Doctoral Dissertation. Ohio University.

Ming-Che, C., Rong-Chang, J., Cing-Chu, L., \& Chung-Wei, K. (2013). Workplace Stress, Job Satisfaction, Job Performance and Turnover Intention of Health Care Workers in Rural Taiwan. Asia-Pasific of Journal Public Health XX(X), 1-10.

Morgeson, P, F \& Humphrey, E, S. (2006). The Work Design Questionnaire (WDQ): Developing and Validating a Comprehensive Measure for Assessing Job Design and the Nature of Work. Journal of Applied Psychology, 91(6), 1321-1339. American Psychological Assosiation.

Morgeson, F. P., Delaney-Klinger, K., \& Hemingway, M. A. (2005). The importance of job autonomy, cognitive ability, and job-related skill for predicting role breadth and job performance. Journal of Applied Psychology, 90, 399-406.

Mowday, R. T., Porter, L. M. \& Steers, R. M. (1982). Employee-Organizational Linkage: The Psychology of Commitment, Absenteeism, and Turnover. New York: Academic Press.

Naqvi, R, M, M, S., Isgtiaq, M., Kanwal, N., \& Ali, M. (2013). Impact of Job Autonomy on Organizational Commitment and Job Satisfaction: The Moderating Role of Organizational Culture in Fast Food Sector of Pakistan. International Journal of Bussiness and Management, 8(17). Canadian Center of Science and Education.

Polii, L, R, G. (2015). Analisis Keterikatan Karyawan Terhadap Pekerjaan Dan Lingkungan Kerja Terhadap Kepuasan Kerja Dan Turnover Intentions Karyawan Di Rumah Sakit Siloam Manado. Jurnal Riset Ekonomi, Manajemen, Bisnis Dan Akuntansi, 3(4).

Priyanka, L. (2017). Peningkatan Efektivitas Media Development Program di Salah Satu Stasiun Televisi Swasta Nasional. Jurnal Kajian Bisnis Indonesia, 1(1), 155-126. Universitas Prasetya Mulya: Jakarta.

Putri, R, I. A., \& Suana, I. W (2016). Pengaruh Job Embeddedness, Kepuasan Kerja, Dan Komitmen Organisasional Terhadap Turnover Intention Karyawan. Jurnal Manajemen Universitas Udayana, 5(7).

Robbins, P,S \& Judge, A, T. (2015). Perilaku Organisasi. Edisi 16 Bahasa Indonesia. Salemba Empat: Jakarta. 
Robert, C \& Satrya, A. (2013). Pengaruh Otonomi kerja dan Autonomy Support Terhadap Turnover Intention Melalui Mediator Pemberdayaan psikologis (Studi Kasus Pada Karyawan TI di Empat Perusahaan). Jurnal Publikasi Ilmiah. Fakultas Ekonomi dan Bisnis: Universitas Indonesia.

Saragih, S. (2011). The Effects of Otonomi kerja n ork Outcomes: Self Efficacy as an Intervening Variabel. International Research Journal of Business Studies, 4(3), 203-215. Universitas Kisten Maranatha Bandung.

She, C. K., Thoong, S. L., See, S. N., Qing, H. T., \& Sin, W. T. (2013). A Study on Factors That Impact Turnover Intention of Employees Among SME Firms in ICT Industry. Journal of Business Administration (HONS). Tunku Abdul Rahman University.

Spreitzer, M, G. (1995). Psychological Empowerment in Workplace Dimentions, Measurement and Validation. The Academiy of Management Journal, 38(5), 1442-1465.

Sugiyono. (2003). Metode Penelitian Bisnis. Edisi 1. Bandung: Alfabeta.

Sutanto, M, E. (2013). Kepuasan Kerja, Komitmen Organisasional dan Turnover Intentions. Jurnal Mitra Ekonomi dan Manajemen Bisnis, 4(1), 76-88. Universitas Kristen Petra.

Tett, R,P \& Mayer, J,P, (1993). Job Satisfaction, Organizational Commitment, Turnover Intention, And Turnover: Path Analyses Based On Metaanalytic Findings. Personel Psychology, 46 pp, 259-293.

Thomas, K. W., \& Velthouse, B. A. (1990). Cognitive elements of empowerment: An "interpretive" model of intrinsic task motivation. Academy of Management Review, 15, 666681.

Thompson, C. A., \& Prottas, D. J. (2006). Relationships among organizational family support, job autonomy, perceived control, and employee well-being. Journal of Occupational Health Psychology, 11(1), 100-118.

Tribowo, E \& Dhewanto, W. (2015). Ekonomi Kreatif: Rencana Pengembangan Televisi dan Radio Nasional 2015-2019. Republik Solusi 2015.

Toly, A. A. (2001). Analisis Faktor-Faktor yang Mempengaruhi Turnover Intention pada Staff Kantor Akuntan Publik. Jurnal Akuntansi dan Keuangan, 3(2).

Yang, S.B., \& Lee, K.H. (2009). Linking empowerment and job enrichment to turnover intentions: The influence of job satisfaction. International Review of Public Administration, 14(2), 13-23.

Wahyuni, S, A., Zaika, Y,. \& Anwar, R. (2014). Analisis Faktor-faktor yang Mempengaruhi Turnover Intention (Keinginan Berpindah) Karyawan Pada Perusahaan Jasa Konstruksi. Jurnal Rekayasa Sipil, 8(2). Universitas Brawijaya.

Wang, A. C., \& Cheng, B. S. (2010). When does benevolent leadership lead to creativity? The moderating role of creative role identity and job autonomy. Journal of Organizational Behavior, 31, 106-121. 